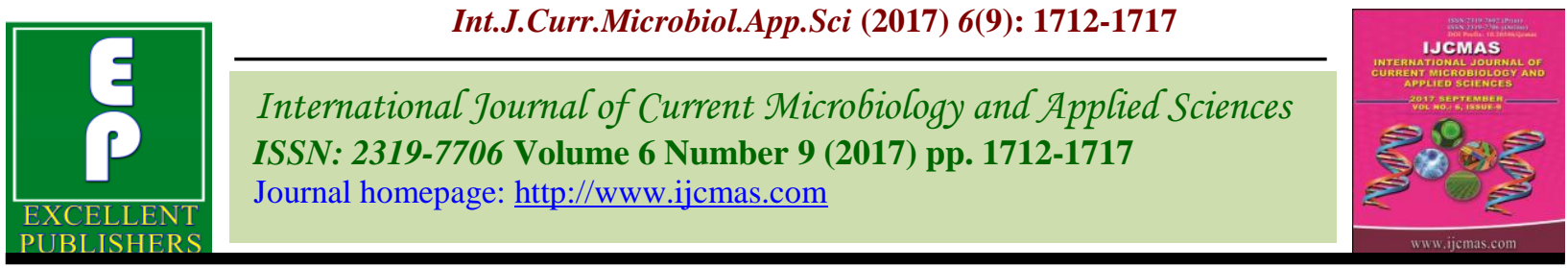

Case Study

https://doi.org/10.20546/ijcmas.2017.609.211

\title{
Impact Assessment of Farm Ponds on Beneficiaries
}

\author{
J.M. Deshmukh*, V.D. Hyalij, D.D. Suradkar and B.B. Badgire \\ Department of Extensiojn Education, College of Agriculture, Latur, Maharashtra, India \\ *Corresponding author
}

\section{A B S T R A C T}

Keywords

Impact, Farm pond, Beneficiaries

Article Info

Accepted:

21 July 2017

Available Online:

10 September 2017
The present study was conducted in Latur, Renapur and Ausa tahsils of Latur district from Marathwada region of Maharashtra state, with an objective to study the impact of farm pond on beneficiaries. Four villages from each tahsil were selected randomly. Total twelve villages were selected for research study. Ten respondents from each village were selected purposively to comprise a sample of 120 respondents. One short case study method of ex-post-facto medium research design was adopted for this study. It was observed that majority of the respondents belong to medium category of technological change, economic change and social change before farm pond. Also it was observed that most of beneficiaries belong to medium category of technological change, economic change and social change after farm pond

\section{Introduction}

Farm ponds are created in various states of India along with Maharashtra. The main aim of construction farm pond is to make the availability of protective irrigation at critical growth stages of crop.

In Maharashtra through various scheme of government the farm ponds are allotted to farmers namely, National Horticultural Mission, Mahatma Gandhi National Rural Employment Guarantee Act (MGNREGA) and Mahatma Phule Jal Abhiyan etc.

The farm pond has a great impact on changing the crop productivity as well as cropping intensity. It also helps in changing the economic situation of farmers. The irrigated area also increases due to the construction farm pond.
India has been predominantly an agricultural country. Hence, it is true that progress of India is very much dependent on the development of agriculture. The increased agricultural production depends upon the number of factor of which, water play an important role.

Water is an essential and precious resource upon which our ecosystems and agricultural production depend. However, water a natural resource of the world constitutes, 1,384 million cubic kilometers of which around 97.39 per cent (i.e.1,348 million cubic kilometers) of water is in the oceans, which is salty in nature. Another 2.61 per cent (i.e., 36 million $\mathrm{km}^{3}$ ) is fresh water of this 77.23 per cent $\left(27.82\right.$ million $\left.\mathrm{km}^{3}\right)$ is in the polar ice caps, icebergs and glaciers. Only small 
fraction of water resources $(0.59 \%$ or 8.2 million $\mathrm{KM}^{3}$ ) of the earth present on the ground, lakes, rivers and atmosphere and is useful to mankind. Whereas, more than 99 per cent of water present on the earth is not useful to mankind (Anonymous, 2013).

Rainfed agriculture constitutes for 55 per cent of net sown area in the country. The annual average rainfall of the country varies from 400 to more than $2000 \mathrm{~mm}$ varying in both space and time.

In low to medium rainfall rainfed regions, the occurrence of high intense rainfall events with the short duration is very common causing the soil erosion. Hence, the efficient rain water management is necessary to improve water productivity and protect the natural resource base in rainfed regions. Farm pond technology has very good potential for implementation in different schemes of state or central government. Hence the present study was undertaken with the objective to see impact of farm pond on beneficiaries. The main objectives of this study include to assess the impact of farm pond on beneficiaries.

\section{Results and Discussion}

Impact of farm pond was major in relation to technological change, economic change and social change.

In absence of proper bench mark observations, the study attempted comparison between beneficiaries before and after use of farm pond respectively. For the reason that all the situational, administrative, climatic and other such forces should be common to both.

It was assumed that whatever the higher change would be observed in use of farm pond. Therefore, in order to isolate impact of farm pond the comparison between after and before use of farm pond was made.

\section{Technological changes}

\section{Change in crop productivity}

It was observed from table 1 that, 73.33 per cent of beneficiaries after and 68.33 per cent before having medium crop productivity for cotton whereas, 11.67 per cent of beneficiaries were having high crop productivity in cotton crop as against none of farm pond beneficiaries before were present in this category while only 15.00 per cent after and 31.67 per cent before beneficiaries having low crop productivity.

Mean crop productivity of cotton crop of beneficiaries was 20.07 and mean crop productivity of cotton crop of and 11.75 after and before use of farm pond respectively, calculated ' $Z$ ' value showed that there was significant difference in productivity of cotton after use of farm pond.

Table 1 further elaborates that majority $(71.66 \%)$ of after and 70.00 per cent before having medium crop productivity for sorghum crop. Whereas, 18.34 per cent and 26.66 per cent were having low crop productivity for sorghum while, 10 per cent and 3.34 per cent of beneficiaries were having higher crop productivity in sorghum after and before use of farm pond respectively.

Mean of crop productivity of sorghum of beneficiaries after use of farm pond was 18.13 and mean of crop productivity of before farm pond was 11.27 , calculated ' $\mathrm{Z}$ ' value showed that difference between crop productivity of sorghum in beneficiaries was significant.

It was also observed from table 1 that majority $(71.66 \%)$ of beneficiaries after farm pond and 55.00 per cent beneficiaries were having medium crop productivity before farm pond for wheat crop. Whereas, only 20.00 per cent of and 43.33 per cent were having lower 
crop productivity for wheat after and before farm pond respectively. While, 08.34 per cent of beneficiaries (after) and only 01.67 per cent of beneficiaries (before) were having higher crop productivity of wheat.

Mean crop productivity of wheat of beneficiaries (after) was 19.20 and mean crop productivity of wheat of beneficiaries (before) was 9.17 respectively, calculated ' $Z$ ' value showed that difference in crop productivity of wheat between beneficiaries after and before farm pond was significant.

Table 1 further revealed that more than half $(51.66 \%)$ of beneficiaries (after farm pond) and 50.00 per cent of beneficiaries (before farm pond) were having medium crop productivity for redgram whereas, 30.00 per cent of beneficiaries (after) and 48.33 per cent of beneficiaries (before) were having lower crop productivity for red gram while, 18.34 per cent of beneficiaries (after) and only 1.67 per cent of beneficiaries (before farm pond) were having higher crop productivity of red gram.

Mean crop productivity of red gram of beneficiaries was 9.34 and 4.15, after and before use of farm pond respectively, calculated ' $\mathrm{Z}$ ' value showed that there was significant difference in crop productivity of red gram between beneficiaries.

\section{Change in cropping pattern}

It was revealed from table 2 that more than three fifth $(65.00 \%)$ of beneficiaries (after farm pond) and 40.00 per cent of beneficiaries (before farm pond) were belonged to medium change in cropping pattern, whereas, only 18.33 per cent of beneficiaries and majority 56.66 per cent of beneficiaries were found in lower category of change in cropping pattern while, 16.67 per cent and only 334 per cent of beneficiaries after and before respectively, showed high change in cropping pattern.

Mean of change in cropping pattern index beneficiaries (after) was 53.64 and that of before was 35.57, calculated ' $Z$ ' value showed that difference in change in cropping pattern between beneficiaries after and before farm pond was significant.

\section{Soil conservation structure}

It was revealed from table 3 that 75.00 per cent, 63.34 per cent, 55.00 per cent and 38.34 per cent of beneficiaries were done land leveling, graded bunding, broad bed furrow and nala training respectively.

Table.1 Distribution of the respondents according to change in crop productivity

\begin{tabular}{|c|c|c|c|c|c|c|c|c|c|}
\hline \multirow[t]{3}{*}{ Crops } & \multicolumn{8}{|c|}{ Beneficiaries } & \multirow[t]{3}{*}{ Z Value } \\
\hline & \multicolumn{4}{|c|}{ Before } & \multicolumn{4}{|c|}{ After } & \\
\hline & Low & Medium & High & Mean & Low & Med. & High & Mean & \\
\hline Cotton & $\begin{array}{c}38 \\
(31.67)\end{array}$ & $\begin{array}{c}82 \\
(68.33)\end{array}$ & - & 11.75 & $\begin{array}{c}18 \\
(15.00)\end{array}$ & $\begin{array}{c}88 \\
(73.33)\end{array}$ & $\begin{array}{c}14 \\
(11.67)\end{array}$ & 20.07 & $5.518 * *$ \\
\hline Sorghum & $\begin{array}{c}32 \\
(26.66)\end{array}$ & $\begin{array}{c}84 \\
(70.00)\end{array}$ & $\begin{array}{c}4 \\
(3.34)\end{array}$ & 11.27 & $\begin{array}{c}22 \\
(18.34)\end{array}$ & $\begin{array}{c}86 \\
(71.66)\end{array}$ & $\begin{array}{c}12 \\
(10.00)\end{array}$ & 18.13 & $4.198 * *$ \\
\hline Wheat & $\begin{array}{c}52 \\
(43.33) \\
\end{array}$ & $\begin{array}{c}66 \\
(55.00) \\
\end{array}$ & $\begin{array}{c}2 \\
(1.67) \\
\end{array}$ & 9.17 & $\begin{array}{c}24 \\
(20.00) \\
\end{array}$ & $\begin{array}{c}86 \\
(71.67) \\
\end{array}$ & $\begin{array}{c}10 \\
(8.34) \\
\end{array}$ & 19.20 & $5.373 * *$ \\
\hline Redgram & $\begin{array}{c}58 \\
(48.33) \\
\end{array}$ & $\begin{array}{c}60 \\
(50.00)\end{array}$ & $\begin{array}{c}2 \\
(1.67) \\
\end{array}$ & 4.15 & $\begin{array}{c}36 \\
(30.00) \\
\end{array}$ & $\begin{array}{c}62 \\
(51.66) \\
\end{array}$ & $\begin{array}{c}10 \\
(18.34)\end{array}$ & 9.34 & $4.829 * *$ \\
\hline
\end{tabular}

** Significant at 0.01 level of probability.

(Figures in parentheses indicate the percentage.) 
Table.2 Distribution of the respondents according to change in cropping pattern

\begin{tabular}{|c|c|c|c|c|c|c|c|c|}
\hline \multicolumn{8}{|c|}{ Extent of Change } & \multirow[t]{3}{*}{ Z Value } \\
\hline \multicolumn{4}{|c|}{ Before } & \multicolumn{4}{|c|}{ After } & \\
\hline Low & Medium & High & Mean & Low & Medium & High & Mean & \\
\hline $\begin{array}{c}68 \\
(56.66)\end{array}$ & $\begin{array}{c}48 \\
(40.00)\end{array}$ & $\begin{array}{c}4 \\
(6.68)\end{array}$ & 35.57 & $\begin{array}{c}22 \\
(18.33)\end{array}$ & $\begin{array}{c}78 \\
(65.00)\end{array}$ & $\begin{array}{c}20 \\
(16.67)\end{array}$ & 53.64 & $5.94 * *$ \\
\hline
\end{tabular}

Table.3 Distribution of the respondents according to change in soil conservation structure

\begin{tabular}{|c|c|c|c|c|c|c|c|c|}
\hline \multirow{2}{*}{$\begin{array}{l}\text { Sr. } \\
\text { No. }\end{array}$} & \multirow{2}{*}{$\begin{array}{l}\text { Name of soil } \\
\text { conservation structure }\end{array}$} & \multicolumn{2}{|c|}{ Before } & \multirow[t]{2}{*}{ Mean } & \multicolumn{2}{|r|}{ After } & \multirow[t]{2}{*}{$\mathbf{M}$} & \multirow[t]{2}{*}{$\mathrm{Z}$ value } \\
\hline & & Freq & Percentage & & Freq & Percentage & & \\
\hline 1 & Land Leveling & 46 & 38.33 & 0.383 & 90 & 75.00 & 0.750 & $4.326 * *$ \\
\hline 2 & Graded Bunding & 28 & 23.33 & 0.233 & 76 & 63.34 & 0.633 & $4.792 * *$ \\
\hline 3 & Broad bed furrow & 34 & 28.33 & 0.283 & 66 & 55.00 & 0.550 & $3.051 * *$ \\
\hline 4 & Nala training & 20 & 16.67 & 0.167 & 46 & 38.34 & 0.383 & $2.718 * *$ \\
\hline
\end{tabular}

Table.4 Distribution of the respondents according to change in employment generation

\begin{tabular}{|c|c|c|c|c|c|c|c|c|}
\hline \multicolumn{8}{|c|}{ Extent of Change } & \multirow[t]{3}{*}{ Z Value } \\
\hline \multicolumn{4}{|c|}{ Before } & \multicolumn{4}{|c|}{ After } & \\
\hline Low & Medium & High & Mean & Low & Medium & High & Mean & \\
\hline $\begin{array}{c}42 \\
(35.00)\end{array}$ & $\begin{array}{c}68 \\
(56.67)\end{array}$ & $\begin{array}{c}10 \\
(8.33)\end{array}$ & 96.55 & $\begin{array}{c}12 \\
(10.00)\end{array}$ & $\begin{array}{c}88 \\
(70.00)\end{array}$ & $\begin{array}{c}24 \\
(20.00)\end{array}$ & 152.60 & $3.386^{* *}$ \\
\hline
\end{tabular}

Table.5 Distribution of the respondents according to change in material possession

\begin{tabular}{|c|c|c|c|c|c|c|c|c|}
\hline \multicolumn{8}{|c|}{ Extent of Change } & \multirow{3}{*}{ Z Value } \\
\hline \multicolumn{4}{|c|}{ Before } & \multicolumn{4}{|c|}{ After } & \\
\hline Low & Medium & High & Mean & Low & Medium & High & Mean & \\
\hline $\begin{array}{c}48 \\
(40.00)\end{array}$ & $\begin{array}{c}60 \\
(50.00)\end{array}$ & $\begin{array}{c}12 \\
(10.00)\end{array}$ & 16.65 & $\begin{array}{c}22 \\
(18.33)\end{array}$ & $\begin{array}{c}68 \\
(56.67) \\
\end{array}$ & $\begin{array}{c}30 \\
(25.00)\end{array}$ & 11.81 & $3.559 * *$ \\
\hline
\end{tabular}

Table.6 Distribution of the respondents according to change in education of family members

\begin{tabular}{|c|c|c|c|c|c|c|c|c|}
\hline \multicolumn{8}{|c|}{ Extent of Change } & \multirow[t]{3}{*}{ Z Value } \\
\hline \multicolumn{4}{|c|}{ Before } & \multicolumn{4}{|c|}{ After } & \\
\hline Low & Medium & High & Mean & Low & Medium & High & Mean & \\
\hline $\begin{array}{c}44 \\
(36.67)\end{array}$ & $\begin{array}{c}50 \\
(41.67)\end{array}$ & $\begin{array}{c}26 \\
(21.66)\end{array}$ & 61.62 & $\begin{array}{c}22 \\
(18.34)\end{array}$ & $\begin{array}{c}56 \\
(46.66)\end{array}$ & $\begin{array}{c}42 \\
(35.00)\end{array}$ & 68.91 & 0.865 \\
\hline
\end{tabular}

Table.7 Distribution of the respondents according to change in implement possession

\begin{tabular}{|c|c|c|c|c|c|c|c|c|}
\hline \multicolumn{8}{|c|}{ Extent of Change } & \multirow[t]{3}{*}{ Z Value } \\
\hline \multicolumn{4}{|c|}{ Before } & \multicolumn{4}{|c|}{ After } & \\
\hline Low & Medium & High & Mean & Low & Medium & High & Mean & \\
\hline $\begin{array}{c}66 \\
(55.00)\end{array}$ & $\begin{array}{c}48 \\
(40.00)\end{array}$ & $\begin{array}{c}6 \\
(5.00\end{array}$ & 5.80 & $\begin{array}{c}30 \\
(25.00\end{array}$ & $\begin{array}{c}78 \\
(65.00)\end{array}$ & $\begin{array}{c}12 \\
(10 . .00)\end{array}$ & 7.72 & $2.995 * *$ \\
\hline
\end{tabular}


Beneficiaries (before farm pond) only 38.33 per cent, 23.33 per cent 28.33 per cent and 16.67 per cent were done land leveling, graded bunding broad bed furrow and nala training respectively.

Mean of land leveling, graded bunding, broad bed furrow and nala training of beneficiaries after farm pond were $0.750,0.633,0.550$ and 0.383 , respectively and that of before farm pond similar soil conservation structure were $0.383,0.233,0.283$ and 0.167 , calculated ' $\mathrm{Z}$ value for each structure were showed that there was significant difference between beneficiaries after farm pond.

\section{Economic changes}

\section{Change in employment generation}

The data in table 4 showed that 70.00 per cent of beneficiaries (after farm pond) and 56.67 per cent before farm pond were belonged to medium category of employment generation, followed by 20.00 per cent of and 08.33 per cent of beneficiaries after and before farm pond were found in high category of employment generation while, in lower category 10.00 per cent beneficiaries and 35.00 per before beneficiaries were present.

Mean of employment generation of beneficiaries after use of farm pond was 152.60 and mean of employment generation beneficiaries before farm pond was 96.550, ' $\mathrm{Z}$ ' value calculated from these mean showed significant difference in employment generation.

\section{Social changes}

\section{Change in material possession}

It is revealed from table 5 that more than half $(56.67 \%)$ of beneficiaries after and half 50.00 per cent of beneficiaries before farm pond were present in medium category of material possession followed by, 25.00 per cent of beneficiaries after and 10.00 per cent of beneficiaries before farm pond belonged to higher category of material possession while, 40.00 per cent of beneficiaries after and 18.33 per cent of beneficiaries before farm pond found lower category of material possession.

Mean of material possession of beneficiaries after farm pond was 11.81 and that of before farm pond were 09.51 , ' $\mathrm{Z}$ ' value calculated from these mean showed there was significant difference of material possession between beneficiaries.

\section{Change in education of family members}

Table 6 elaborate that less than half $(46.66 \%)$ of beneficiaries after and 41.67 per cent of beneficiaries before were medium category of education of family members whereas, 35.00 and 21.66 per cent of beneficiaries were present in high category of education after and before respectively of family members while, 18.34 per cent of and 36.67 per cent of beneficiaries after and before farm pond were present in lower category of education of family members.

Mean of extent of education of family members was 68.91 and that of before mean was 61.62 , calculated ' $\mathrm{Z}$ ' value showed that there was no significant difference in education of family members of beneficiaries.

\section{Change in implement possession}

It was revealed from table 7 that, majority $(65.00 \%)$ of beneficiaries after and 40.00 per cent of beneficiaries before farm pond were present medium category of implement possession but in lower category of implement possession majority $(55.00 \%)$ of beneficiaries before farm pond were present. Whereas, 25.00 per cent of beneficiaries were 
present in said category. In higher category 10.00 per cent of beneficiaries after and 5.00 per cent of beneficiaries before were present.

Mean of implement possession of beneficiaries after farm pond was 7.233 and that of beneficiaries before farm pond was 5.800 calculated ' $\mathrm{Z}$ ' value showed that difference in implement possession between beneficiaries after farm pond.

\section{Technological change}

Technological changes were measured in terms of change in crop productivity, change in cropping pattern and soil conservation structure. It was observed thus at individual level beneficiaries showed medium change in respect of technological change before use of farm pond.

\section{Economic change}

Economic change was measured in terms of change in employment generation at individual level, beneficiaries created more employment opportunities, after construction of farm pond.

\section{Social change}

Social change was measured in terms of change in material possession, change in education of family members and change in implement possession. The data revealed that medium change in material possession, implement possession and education of family members after farm pond.

\section{References}

Anonymous, 2013. Impact of farm ponds on beneficiary farmers of Western Vidarabha, Research Review Committee Project, submitted on 2nd April, 2013 at RRC meeting Dr. Punjanbrao Deshmukh Krishi Vidyapeeth, Akola.

Deshmukh, P. R., Kadam, P., and Shinde, V. N. 2007. Knowledge and adoption of agriculture technologies in Marathwada. Indian Res. J. Extn. Educ. 7(1): 41-42

Dighe, A.G., and Rajput, U. U.2010.Adoption of soil and water conservation practices by the farmers in Vidarbha, Maharashtra. Agriculture Update, 5(1 \& 2): 191-193.

Kulshrestha, A., Kushwaha, T. S., Singh, Y. $\mathrm{K}$ and Rai, D. P.2010.Adoption of Watershed Technologies by the farmers in Morena district of Madhya Pradesh. Indian Res. J. Ext.Edu., 10(2): 58-60.

Rawat, A., Sathwane, R. A., Singh, S., Dhakad, K. S. and Niranjan, H. K. 2012. Management pattern of sustainable livelihood diversification among small and marginal farmers in Shahdol district of Madhya Pradesh. Life Science Bulletin. 9(2): 399- 401.

\section{How to cite this article:}

Deshmukh, J.M., V.D. Hyalij, D.D. Suradkar and Badgire, B.B. 2017. Impact Assessment of Farm Ponds on Beneficiaries. Int.J.Curr.Microbiol.App.Sci. 6(9): 1712-1717. doi: https://doi.org/10.20546/ijcmas.2017.609.211 